\title{
PENDIDIKAN KOLONIAL DAN POLITIK ASOSIASIs KAJIAN ATAS MEMOAR PANGERAN ARIA ACHMAD DJAJADININGRAT (1877-1943)
}

\author{
COLONIAL EDUCATION AND ASSOCIATED POLITIC: \\ A STUDY OF PANGERAN ARIA ACHMAD DJAJADININGRAT MEMOIRS \\ (1877-1943)
}

\author{
Iim Imadudin \\ Balai Pelestarian Nilai Budaya Bandung \\ Jln. Cinambo No.136 Ujungberung-Bandung 42094 \\ e-mail: iim.imadudin@yahoo.com
}

Naskah Diterima:8 Januari $2014 \quad$ Naskah Direvisi:12 Februari $2014 \quad$ Naskah Disetujui:18 Februari 2014

\begin{abstract}
Abstrak
Penulisan artikel ini didasari perdebatan bagaimana sesungguhnya peranan para pangreh praja didikan Barat dalam perjuangan kemerdekaan. Oleh karena berada dalam pemerintahan Hindia Belanda, mereka dianggap tidak berkontribusi dalam perjuangan kemerdekaan. Bahkan, mereka dianggap merintangi gerak langkah kaum pergerakan sehingga sering dianggap sebagai lawan politik. Penelitian ini bertujuan mengungkap sejarah pemikiran dan mentalitas dari salah seorang bupati terkemuka pribumi asal Banten, Ahmad Djajadiningrat, melalui memoarnya yang berjudul Memoar Pangeran Aria Djajadiningrat. Pangeran Aria Ahmad Djajadiningrat mengikuti pendidikan mulai dari HIS, ELS, hingga HBS di Batavia. Berbagai jabatan di pemerintahan diembannya, mulai dari bupati, anggota Volksraad, mindere welvaart comissie, hingga anggota Raad van Indie. Penelitian ini mempergunakan metode sejarah yang terdiri atas heuristik, kritik, interpretasi, dan historiografi. Hasil penelitian menunjukkan Ahmad Djajadiningrat di satu sisi menjadi pemimpin tradisional yang kharismatis dan aparat pemerintah yang loyal, namun di sisi lain bersikap kritis terhadap kebijakan pemerintah Hindia Belanda dan mendorong berkembangnya pergerakan nasional di tanah Banten.
\end{abstract}

Kata kunci: pendidikan kolonial, politik asosiasi, Achmad Djajadiningrat.

\section{Abstract}

The writing of this article is based on the actual debate on what the role of Western-based education of pangreh pradja is in the struggle for independence. Because it is in the Dutch East Indies, they are considered not to be contributing to the struggle for independence. In fact, they were considered to hinder the movement of the steps that are often regarded as political opponents. This study aims to reveal the history of thought and mentality of anative and famousleader from Banten, Ahmad Djajadiningrat, through his memoirs entitled Memoirs of Prince Aria Djajadiningrat. The Prince Aria Ahmad Djajadiningrat started his education in HIS, ELS, to HBS in Batavia. The various positions in government was held, ranging from the regents, members of the Volksraad, mindere Welvaart comissie, until become a member of the Raad van Indie. This study uses historical method which consists of heuristics, criticism, interpretation, and historiography. The results shows that Ahmad Djajadiningrat isa traditional charismatic leader and a loyal government official. On the other hand, he is critical to the Dutch East Indies government policies and encouraging the development of a national movement in Banten.

Keywords: colonial education, political association, Achmad Djajadiningrat. 


\section{A. PENDAhULUAN}

Gerry van Klinken memberi pernyataan yang menarik tentang penulisan biografi di Indonesia. Baginya, hal tersebut semacam ironi bagi bangsa dengan masyarakatnya yang cenderung rendah hati, buku-buku biografi yang terbit terkesan menonjolkan diri sendiri, jika tidak hendak dikatakan egois. Sang tokoh selalu berada di depan, aktif, dan sekuat tenaga mengikuti teladan para tokoh pahlawan terkemuka (Klinken, 2008: 125).

Van Klinken membandingkan penulisan biografi di Barat dengan Indonesia. Bila biografi di Barat menempatkan kehidupan batin sebagai pokok dari biografi, biografi di Indonesia sangat berorientasi tindakan (action oriented). Kehidupan batin jarang ditampilkan dalam biografi-biografi di Indonesia, khususnya pada era Orde Baru (klinken, 2008: 133).

Pernyataan di atas merupakan bagian dari persoalan subjektivitas yang dimiliki penulis biografi. Ada beberapa kesulitan yang kerap menghadang seorang penulis biografi. Keterlibatan secara subjektif membuat seseorang tidak bisa berpikir objektif. Ia tidak bisa mengambil jarak dari objek yang dikajinya. Belum lagi "hambatan ekstern" yang sering memberikan keterbatasan dalam penafsiran. Seorang penulis biografi yang bukan berasal dari latar belakang budaya sang tokoh lebih memiliki peluang untuk tidak terbebani secara kultur. Pada akhirnya, seorang penulis biografi hanya akan dianggap berhasil jika ia mampu menangkap ketokohan objeknya dan alasan mengapa layak untuk ditulis.

Biografi merupakan riwayat hidup tokoh yang ditulis oleh orang lain baik tokoh tersebut masih hidup atau sudah meninggal. Sementara riwayat hidup yang ditulis sendiri disebut otobiografi. Otobiografi lebih bersifat pengalaman nyata (Daud, 2013: 245). Dalam bahasa Kuntowijoyo otobiografi merupakan refleksi otentik dari pengalaman seseorang. Memoar mempunyai kedekatan makna dengan otobiografi; titik perbedaannya adalah memoar ditulis oleh tokoh tersebut mengenai satu peristiwa saja (Kuntowijoyo, 2003: 205).

Mengenai topik artikel ini, ada beberapa hal yang melatarbelakangi penulisannya. Pertama, dari sisi signifikansinya, Memoar P.A.A. Djajadiningrat mewakili suatu kurun lahirnya elit modern sebagai akibat berkembangnya pendidikan Barat. Buku ini memiliki makna yang penting, karena sebagaimana disebutkan Drewes, merupakan suatu pertanda zaman "uiterst boeiend en levendig" yang sangat memikat dan hidup (Swantoro, 2002: 62). Kedua, dari sisi ketersediaan sumber, memoar ini tentu merupakan sumber primer dalam penulisan mengenai peranan P.A.A. Djajadiningrat. Ketiga, dari sisi teknis, sumber-sumber yang lebih umum tentang P.A.A. Djajadiningrat cukup banyak tersedia. Keempat, merujuk pada pernyataan Klinken, Memoar P.A.A. Djajadiningrat berbeda dengan kebanyakan biografi yang ditulis pada masa Orde Baru. Memoar ini menggambarkan pergulatan batin dan intelektual penulisnya.

Penulisan yang secara khusus berkaitan dengan biografi Achmad Djajadiningrat masih sangat terbatas. Umumnya literatur yang tersedia menempatkan posisi Ahmad Djajadiningrat dalam politik asosiasi dan peranannya dalam pemerintahan Hindia Belanda. Robert van Niel (1984) menyebut Ahmad dan Hussein Djajadiningrat merupakan percontohan keberhasilan kebijakan politik asosiasi. Snouck dinyatakan berhasil menguasai sebagian kaum ningrat Banten untuk mengikuti pendidikan cara Barat. Sejak angkatan Ahmad Djajadiningrat, lebih banyak lagi para priyayi yang menyekolahkan anaknya mengikuti pendidikan Barat (van Niel, 1984: 71).

Habsjah (2007) menyebut Ahmad Djajadiningrat sebagai bupati intelektual merupakan satu dari empat bupati yang mampu berbicara dan menulis dalam 
bahasa Belanda. Djajadiningrat bersama Koeseomo Oetojo termasuk bupati generasi baru yang tumbuh dalam situasi rasionalisasi birokrasi yang menggoyahkan kepemimpinan bupati menurut garis keturunan. Demikian pula Heather Sutherland (1983) menyebut Achmad Djajadiningrat sebagai putra Bupati Serang yang sadar akan arti pentingnya pendidikan. Tirta (2012) menyebut Achmad Djajadiningrat sebagai salah satu pejabat pribumi yang paling menonjol pada permulaan abad ke-20. Ia adalah tokoh penting dalam pemerintahan lokal maupun dalam dewan rakyat Volksraad di Hindia Belanda. Sejumlah literatur yang sudah disebutkan hanya membahas peranan Achmad Djajadiningrat secara selintas dan parsial.

Di antara sedikit tulisan yang terpenting adalah Memoar Pangeran Aria Achmad Djajadiningrat yang diterbitkan Paguyuban keturunan Pangeran Aria Achmad Djajadiningrat (1996). Buku ini terbit pertama kali pada tahun 1936 dalam bahasa Belanda dengan judul Herinneringen van Pangeran Aria Achmad Djajadiningrat. Achmad menulisnya selama satu tahun sejak pertengahan tahun 1933. Selain itu, ada karya CW Watson, $O f$ Self and Nation: Autobiography and the Representation of Modern Indonesia (2000). Watson menulis The Metamorphosis of a Javanese Aristocrate: The Memoirs of Pangeran Achmad Djajadiningrat. Memoar Achmad Djajadiningrat digambarkannya sebagai pertemuan dua kebudayaan dalam perjalanan hidup Ahmad Djajadiningrat antara Asia dan Eropa.

Memoar Achmad Djajadiningat mungkin lebih tepat disebut sebagai otobiografi. Bila memoar hanya memotret satu peristiwa penting atau tonggak tertentu dalam kehidupan seseorang, otobiografi memotret lebih lengkap (Daud, 2013: 243). Hal tersebut lebih tepat untuk karya Achmad Djajadiningrat yang merupakan refleksi otentik pengalaman sang perintis intelektual pribumi lulusan
Barat generasi pertama itu. Dalam versi Indonesia herinneringen diterjemahkan menjadi kenang-kenangan. P. Swantoro berpendapat memoar ini lebih merupakan otobiografi ketimbang memoar (Swantoro, 2002: 58).

Kajian kritis terhadap memoar atau otobiografi dapat dikategorikan sebagai sejarah intelektual yang mencoba mengungkap latar belakang sosio-kultural para pemikir, agar dapat mengekstrapolasikan faktor-faktor sosiokultural yang memengaruhinya. (Kartodirdjo, 1992: 181).

Sejarah intelektual mengkaji mentifact dalam segala bentuknya, seperti pikiran, ide, kepercayaan, angan-angan dan segala unsur kesadaran (Supardan, 2009: 300). Jadi, sejarah intelektual adalah studi sejarah tentang peran ide atau gagasan, atau pemikiran dalam proses dan kejadian sejarah (Pranoto, 2010: 81).

Aspirasi pokok sejarah intelektual ialah Zeitgeist (jiwa zaman) dan pandangan sejarah idealistik yang berpendapat bahwa pikiran-pikiran memengaruhi perilaku. Untuk penelitian biografis, Kuntowijoyo menganjurkan penggunaan sensibility daripada zeitgeist. Jiwa zaman terlalu spekulatif dan abstrak. Sensibilitas berarti kandungan emosional suatu kurun sejarah. Konsep sensibilitas lebih dekat dengan sejarah dan psikologi, jadi lebih cocok untuk kajian biografis (Kuntowijoyo, 2002: xix).

Artikel ini mencoba menganalisis memoar Ahmad Djajadiningrat dalam konteks pendidikan kolonial dan politik asosiasi. Selain itu, diungkap pula pergulatan batinnya yang memaksanya hidup di dua sisi: menjadi pegawai pemerintah dan pemimpin tradisional.

\section{B. METODE PENELITIAN}

Penulisan artikel ini menggunakan metode sejarah, yang terdiri atas empat tahapan. Tahap pertama, heuristik, yaitu melakukan pencarian sumber terhadap objek yang diteliti. Dalam hal ini, kedudukan dan peranan Achmad 
Djajadiningrat. Pencarian sumber dilakukan melalui penelitian di perpustakaan beberapa perpustakaan, antara lain di Bandung: perpustakaan BPNB Bandung, Perpustakaan Cisral Unpad, Perpustakaan Wilayah Jawa Barat, dan Jakarta: Perpustakaan Universitas Indonesia. Sumber utama artikel ini adalah Memoar Achmad Djajadiningrat.

Setelah proses heuristik dianggap memadai, kemudian dilakukan kritik sebagai tahap selanjutnya dari metode sejarah. Kritik terbagi dua, yaitu kritik ekstern dan kritik intern. Kritik ekstern bertujuan untuk menentukan otentisitas sumber dengan cara memberikan penilaian terhadap kondisi fisik sumber tersebut. Sementara itu, kritik intern dilakukan dengan melakukan penilaian instrinsik terhadap sumber tersebut. Kemudian bila terdapat data yang simpang-siur dilakukan perbandingan beberapa sumber atau dengan fakta-fakta yang ada sebelumnya. Kritik dengan dasar sumber yang ada akan menguji apakah pendidikan kolonial berhasil mencapai tujuan yang digariskan dalam politik asosiasi dan bagaimana Achmad Djajadiningrat memposisikan dirinya pada masa pergerakan. Tahap ketiga adalah tahap interpretasi, tahap menafsirkan fakta yang membutuhkan kerangka dan dasar pengertian objek penelitian, dan dilakukan dengan bantuan konsep dan teori. Tahap terakhir adalah penulisan sejarah, fakta-fakta yang telah diinterpretasikan dituliskan dalam suatu penulisan yang sistematis dan kronologis.

\section{HASIL DAN BAHASAN}

\section{Gambaran pendidikan kolonial} di daerah Banten

Politik pendidikan merupakan kebijakan terpenting yang dihasilkan pemerintah Hindia Belanda. Itulah sebabnya sering dikatakan bahwa politik pendidikan bukan hanya bagian dari politik kolonial akan tetapi merupakan inti politik kolonial (Nasution, 2011: 3).

Kebutuhan pemerintah Hindia Belanda untuk menyelenggarakan pendidikan di tanah jajahan lebih berorientasi pada semangat kolonialisme itu sendiri, yaitu pendidikan sebagai instrumen penyangga kekuasaan politik penjajahan (Zed, 2012: 174).

Birokrasi pemerintahan kolonial yang terus berkembang memerlukan banyak pegawai. Oleh karena itu diperlukan tenaga-tenaga administratif yang berasal dari kalangan pribumi. Faktor pendidikan menjadi syarat bagi kaum bumiputra untuk menjadi pegawai. Sistem pendidikan yang dibangun sejak awal abad ke-20 telah menciptakan suatu golongan baru dalam masyarakat pribumi, yaitu sebagai pegawai pemerintahan dengan keahlian tertentu yang masuk dalam elit birokrasi Belanda (Binnenlands Bestuur) (Ismarini, 2014: 180).

Beberapa ciri umum politik pendidikan kolonial Belanda sebagai berikut:

1. Gradualisme yang luar biasa dalam penyediaan pendidikan bagi anak-anak Indonesia;

2. dualisme dalam pendidikan dengan menekankan perbedaan yang tajam antara pendidikan Belanda dan pribumi;

3. kontrol sentral yang kuat;

4. keterbatasan tujuan sekolah pribumi, dan peranan sekolah untuk menghasilkan pegawai sebagai faktor penting dalam perkembangan pendidikan;

5. prinsip konkordansi yang menyebabkan sekolah di Hindia Belanda sama dengan di Belanda; dan

6. tidak adanya perencanaan pendidikan yang sistematis untuk pendidikan anak pribumi (Nasution, 2011: 20).

Politik pendidikan kolonial Belanda dilandasi oleh kekhawatiran terhadap Islam yang menjadi agama mayoritas bangsa di Hindia Belanda. Dalam sudut pandang tersebut, gerakan Islam dipandang mengancam kebijakan rust en orde (Keamanan dan Ketertiban), bahkan berpengaruh terhadap kolonialisme di tanah Hindia Belanda. Oleh karena itu, politik pendidikan sangat dipengaruhi oleh 
pemikiran untuk menghilangkan pengaruh Islam dari rakyat jajahannya.

Gagasan tersebut, terutama diinisiasi oleh Snouck Hurgronje ${ }^{1}$. Melalui politik asosiasi $^{2}$, ia meyakini pendidikan Barat akan mampu menjauhkan rakyat bumi putra terhadap Islam. Hurgronje berasumsi kaum pribumi terdidik relatif mampu menjaga jarak dengan Islam. Selain itu, dengan latar pendidikan Barat yang dimilikinya mudah menyerap nilai-nilai Barat. K.F. Holle bahkan menyarankan pengajaran bahasa latin menggantikan bahasa Arab pada sekolah-sekolah di tanah Sunda. Dalam penyelenggaraan pendidikan hendaknya dijauhkan unsur Islam. Pemerintah Hindia Belanda mengikuti nasihatnya menganggap Islam sebagai sesuatu yang berbahaya (Moriyama, 2005: 25).

Pendidikan Barat diyakini menjadi media yang efektif untuk menaklukkan pengaruh Islam di tanah Hindia Belanda. Jadi, yang dibayangkan Hurgronje adalah lahirnya elit baru yang berakar pada elite

\footnotetext{
${ }^{1}$ Snouck Hurgronje merupakan lulusan Leiden yang mengambil spesialisasi masalah agama Islam. Setelah mengajar di Leiden, ia menjadi penasihat pemerintah Hindia Belanda, mempelajari Islam di Jawa dan daerah lainnya di Hindia, terutama di Aceh, tempat terjadinya peperangan yang hebat. Sejak tahun 1906, ia kembali ke Leiden dan pengaruhnya sangat kuat mempengaruhi kebijakan pemerintah Belanda. Ia secara konsisten sangat menganjurkan westernisasi pangreh praja (Sutherland, 1983: 86).
}

2 Politik asosiasi mendorong mayoritas penduduk lokal berasimilasi dengan budaya minoritas, yaitu budaya masyarakat Eropa di Hindia Belanda. Kebijakan ini berorientasi pada terciptanya 'inkorporasi spiritual'. Maksudnya, terpisah jauh secara geografis, akan tetapi terhubung dekat secara batin. Selama masa penjajahan, pemerintah Belanda hanya mampu menguasai penduduk pribumi dalam pengertian administratif. Menurut Snouck Hurgronje, kesatuan budaya akan menghapus perbedaan agama antara orangorang Belanda dan Indonesia secara politik dan sosial (van Dick, 2010: 408). sekular tradisional. Namun, kebijakan pendidikan tersebut melapangkan jalan bagi kelahiran gerakan nasionalis fase pertama. Tentu saja, ide pendidikan bagi anak-anak kaum priyayi memperlihatkan sikap Snouck Hurgronje yang diskriminatif. Hal tersebut menjadi kontradiktif bila dipadankan dengan kebijakan emansipasi yang digagasnya (van Dick, 2010: 408).

Pada mulanya di Banten hanya ada dua sekolah Eropa. Kebanyakan muridnya anak-anak pribumi. Kemudian berkembang sekolah pribumi Serang dan Cilegon. Hanya keduanya tidak dilengkapi fasilitas yang baik.

Memang kebanyakan penduduk belum mempunyai kesadaran tentang pentingnya pendidikan. Meski demikian, upaya-upaya partikelir oleh masyarakat terus diusahakan. Beberapa sekolah yang dirintis tokoh SI tumbuh di Caringin. Namun, sekolah bagi anak perempuan di Serang tidak dipentingkan. Bupati agaknya tidak memberi dorongan yang berarti.

Sekolah OSVIA dan Normaal School berdiri di Serang. ELS berdiri di Serang dan Rangkasbitung. HIS terdapat di Serang, Cilegon, Pandeglang dan Rangkasbitung. Tweede Inlandsche School tersebar di seluruh kabupaten. Di Banten Utara tercatat 177 Sekolah Desa, di Pandeglang 42, dan di Lebak 21 sekolah (ANRI, 1976: xxviii).

Kondisi sekolah-sekolah desa kebanyakan kurang dipelihara dengan baik, karena keterbatasan biaya. Sampai saat ini biaya untuk sekolah-sekolah itu diperoleh dari uang sekolah dan sumbangan dari penduduk. Pemerintah mengusahakan tambahan biaya bagi sekolah-sekolah desa. Bupatinya memerintahkan agar Pulau Liwungan dan Pulau Popole dekat Labuhan dan Citeureup ditanami pohon kelapa. Hasilnya dimanfaatkan untuk membiayai sekolahsekolah desa.

Fasilitas sekolah wilayah Banten jauh dari memadai, termasuk gedung dan perlengkapan sekolah. Meskipun 
demikian, sekolah-sekolah tersebut sejak awal tidak memungut uang sekolah. Barulah uang sekolah dipungut dari siswa, ketika pemerintah memberi putusan.

Sekolah swasta di Banten tidak banyak berkembang. Di Pandeglang dan Rangkasbitung ada sekolah anak-anak perempuan pribumi, sedang di Menes sekolah yang diusahakan oleh Sarekat Islam berkembang baik. Sekolah Cina swasta di daerah Banten ada 6, muridnya berjumlah 290 orang. Sekolah agama yang diselenggarakan oleh 691 pesantren mempunyai murid seluruhnya 11.784 orang, yang diselenggarakan oleh 534 langgar muridnya berjumlah 10.164 orang (ANRI, 1976: xxviii).

\section{Asal-usul P.A.A.Djajadiningrat}

Menurut satu sumber, leluhur Djajawinata masih keturunan Cibeo Kanekes. Raden Wirasuta, anak puun Cibeo Kanekes, diangkat sebagai prajurit oleh Sultan Ageng Tirtayasa (1631-1692). Wirasuta terkenal sebagai ahli berperang. Sultan mengangkatnya sebagai pangeran dan menikahkan dengan salah seorang putrinya. Pangeran Wirasuta wafat ketika memadamkan pemberontakan di Lampung tahun 1663. Ayah dari Djajawinata bernama Raden Adipati Aria Natadiningrat seorang demang patih Caringin Pandeglang. Kakeknya adalah seorang ngabehi Kerajaan Banten yang bertugas di Lebak.

Achmad Djajadiningrat lahir di Desa Kabayan Pandeglang pada tanggal 16 Agustus 1877. Ia terlahir dari pasangan Raden Bagus Djajawinata dan Ratu Salehah. Raden Bagus Djajawinata adalah anak Raden Adipati Aria Natadiningrat yang menjabat Bupati Pandeglang. Sebelumnya, Raden Bagus Djajawinata menjadi wedana di Kramatwatu.

Raden Djajawinata merupakan pangreh praja yang berpikiran maju dan mementingkan pendidikan kolonial. Sebagai dampak dari perubahan sosial, ekonomi, dan politik akibat penetrasi kolonial timbul dinamika internal dalam masyarakat. Elit lama cenderung merasa terancam dengan perubahan itu dan takut akan berpengaruh terhadap kedudukan sosial anak-anak mereka. Mereka membuat reaksi negatif terhadap hal-hal yang berbau modernisasi (Kartodirdjo, 1992: 86; van Niel, 1984: 71). Berbeda dengan kebanyakan elit lama, Raden Djajawinata menyadari nilai penting dari pendidikan yang justru akan memperkuat legitimasi tradisional yang dimiliki para keluarga bupati. Pada awal abad ke-20, minat para priyayi untuk mengikutsertakan anaknya dalam pendidikan Eropa semakin meningkat (van Niel, 1984: 72; Hisyam dan I Ketut Ardhana, 2012: 263).

Pemerintah menghormati hak turuntemurun (erfelijksheidbeginsel) para bupati sejauh berkesesuaian dengan persyaratanpersyaratan birokrasi yang esensial, seperti kemampuan, kerajinan, dan kesetiaan. Pemberian hak turun-temurun kepada keluarga bupati dimaksudkan agar mereka tetap loyal pada pemerintah kolonial (Kartodirdjo, 1984: 128).

Pada praktiknya, pemerintah tidak dapat menghapus peran bupati, karena menduduki status tertinggi dalam struktur sosial tradisional. Kuatnya ikatan feodal antara bupati dengan rakyat turut pula memperkokoh kedudukan bupati (Hardjasaputa, 2004: 57).

Achmad Djajadiningrat menikah dua kali. Pertama, pada tahun 1901, ia menikah dengan Raden Ajeng Lenggang Kencana. Dari penikahan tersebut ia dikaruniai dua anak. Setelah Raden Ajeng Lenggang Kencana meninggal dunia, pada tahun 1910 Achmad menikahi Raden Ajeng Soewitaningrat. Dari pernikahan kedua, ia memeroleh delapan anak.

Adapun putra-putri Djajawinata sebagai berikut: Achmad (Ujang), Muhammad (Apun), Hasan (Emong), dan Hoesein (Ace), Hadijah (Enjah), Lukman (Ujang), Sulasmi (Yayung), Hilman (Imang), dan Rifqi (Kikok).

Keluarga Djajadiningrat memunculkan tokoh-tokoh yang penting. Achmad menjadi bupati dan anggota Volksraad. 
Hoessein menjadi doktor Indologi di Negeri Belanda. Hasan menjadi tokoh gerakan Sarekat Islam di Banten.

\section{Masa Kecil dan Pendidikan}

Pada tahun 1880-an, Achmad kecil mengikuti pendidikan pesantren di Karundang. Inilah fase pertama dalam dunia pendidikan yang dijalaninya.

Kemudian ia mengikuti pendidikan di sekolah swasta Belanda. Mula-mula ia masuk Inlandsche Tweede Klasse School dan kemudian berlanjut ke Europeesche Lagere School yang berada di Jalan Batu Tulis dan Kebon Sirih. Pangeran Aria Achmad Djajadingrat melanjutkan menengahnya ke HBS (Hoge Burgerlijk School) Gymnasium Batavia.

\section{Kiprah di Pemerintahan Hindia Belanda}

Achmad bekerja sebagai pegawai kolonial setelah menyelesaikan pendidikannya di HBS Batavia. Sebagai putra seorang bupati, ia mungkin dengan mudah memeroleh pekerjaan yang baik di birokrasi. Ternyata tidak, sistem yang dibangun kolonial mengharuskannya bekerja pada posisi terbawah. Achmad harus melakukan magang ${ }^{3}$. Tujuannya agar ia mengetahui sopan-santun, etika, dan perilaku seorang pejabat, selain memahami masalah administratif. Agaknya, kerja magang bertujuan politis, yakni mencetak kepala-kepala daerah yang memiliki tingkat loyalitas yang tinggi untuk mempertahankan bentuk administrasi

3 Magang merupakan pekerjaan yang harus dilalui dalam waktu yang tak terbatas bagi seseorang (penduduk pribumi maupun Belanda) sebelum dipercaya menduduki jabatan-jabatan tinggi di lingkungan kerja Pangreh Praja (Inlands bestuur). Dalam kenyataannya, pemagang tidak hanya diberi pekerjaan administratif di kantor sebagai juru tulis (pegawai rendahan) namun juga pekerjaan di luar kedinasan. Sistem kerja magang sempat dihentikan setelah Indonesia merdeka, dan dilanjutkan kembali pada masa Orde Baru (Sudarno, 2006: 6-9). pemerintahannya yang bercorak beamtenstaat (negara pegawai) di lingkungan lembaga Kepangrehprajaan (Sudarno, 2006: 8).

Mula-mula ia magang di kantor kejaksaan Serang pada tahun 1898. Tidak lama kemudian, ia dipindah ke kantor Keresidenan Serang. Pada tahun 1899, ia diangkat sebagai pegawai pemerintah dengan posisi juru tulis kantor Controleur Serang. Kemudian dipindah ke juru tulis distrik Serang. Lalu, ia menjadi asisten wedana di Bodjonegoro (27 Juli 1900-4 Juli 1901). Achmad beruntung, karena hanya setahun menjalani proses kerja magang. Posisi Achmad dalam pemerintahan terus meningkat. Pada tanggal 4 Juli 1901, Achmad menjadi bupati menggantikan ayahnya (Regeering almanak, 1902). Selanjutnya, Achmad menjadi Bupati Batavia (1924-1929). Kepindahannya dari Serang ke Batavia diduga merupakan bagian dari taktik pemerintah kolonial untuk menjauhkan Achmad dari rakyatnya. Tentu saja, keberadaan Achmad di Batavia memudahkan pengawasan pemerintah terhadap dirinya (Tabrani, 1996: 446).

Pada tahun 1902, Achmad terlibat dalam Mindere Welvaart Commissie, bersama Pangeran Ario Hadiningrat (Bupati Demak), dan Raden Mas Tumenggung Koesoemo Oetojo (Bupati Ngawi). Komisi tersebut bertugas menyelidiki tingkat kesejahteraan penduduk pribumi dalam berbagai aspeknya (Titra, 2012: 25). Achmad memanfaatkan keterlibatannya dalam komisi ini untuk untuk mengenal lebih jauh tentang keadaan-keadaan yang mendalam tentang masalah-masalah yang berkaitan dengan penduduk pribumi di daerahnya (Tirta, 2012: 69).

Keterlibatan Achmad dalam NIVB (Nederlandsche Indische Vrijzennige Bond) atau perhimpunan bupati membawanya menjadi anggota Volksraad. NIVB didirikan tahun 1916 yang mewakili orang-orang konservatif. Achmad mendorong agar organisasi ini terlibat 
dalam politik. Namun, sebagian besar anggota menolak untuk terlibat dalam politik. Achmad ingin agar bupati tidak saja sekadar "pemimpin rakyat" tetapi juga "pemimpin kaum muda" yang bersinergi dengan gerakan kebangsaan lainnya (Nagazumi, 1989: 208).

Sejak tahun 1930, Ahmad mengajukan pensiun dari pemerintahan karena sakit. Ahmad Djajadiningrat meninggal pada usia 66 tahun tanggal 25 Desember 1943. Ia dimakamkan di tanah yang sudah dipersiapkannya di Cikampek.

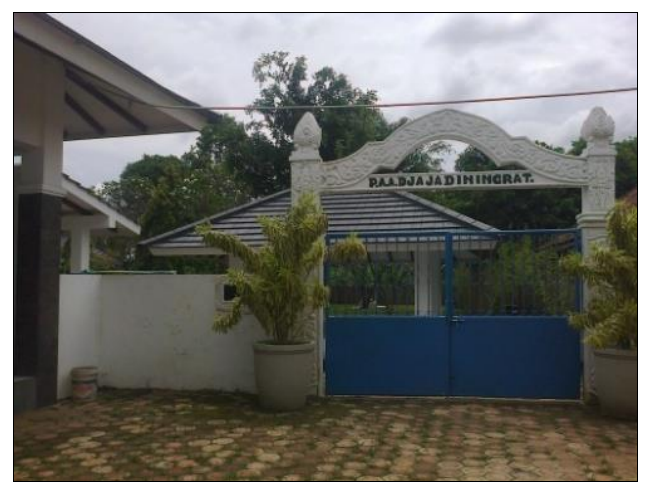

Foto 1. Gerbang Komplek Makam

P.A.A. Djajadiningrat di

Cikampek (Sekarang termasuk Kecamatan

Kota baru) Kab. Karawang.

Sumber: Dok. Penulis, 2015

\section{Garis Besar}

Memoar P.A.A. Djajadiningrat

Bila diperhatikan dalam pengantar penulis memoar terasa adanya dorongan moral penerbitan memoar ini. Memoar ini dianggap merepresentasikan suara pejabat dari pihak Hindia Belanda. Dukungan agar buku ini terbit terutama berasal dari teman sejawat orang pribumi maupun Eropa. Menurut pandangan mereka, Achmad mengalami suatu masa penting dalam sejarah Hindia Belanda, yang menandakan berlangsungnya perubahan dari yang lama ke yang baru.

Memoar ini terdiri atas 10 bab. Bab pertama berisi masa kanak-kanak dan kenangan semasa ayahnya menjadi wedana di Kramatwatu (1882-1888). Bab kedua menceritakan masa muda hingga perkenalannya dengan Snouck Hurgronje
(1888-1890). Bab ketiga mengisahkan pendidikannya di HBS hingga menikah di Ciamis (1890-1899). Bab keempat mengungkap pengalaman bekerja sebagai juru tulis sampai pengangkatannya sebagai asisten wedana (1899-1900). Bab kelima menceritakan kenangannya sebagai Asisten Wedana Bojonegoro hingga pelantikannya sebagai bupati. Bab keenam berkisah tentang pengalamannya selama menjabat Bupati Serang (1901-1906). Bab ketujuh lebih banyak menyuarakan pandangan-pandangannya mengenai gerakan kebangsaan. Bab kedelapan bercerita tentang awal mula kiprahnya di Volksraad, konfliknya dengan resident, hingga pindah ke Batavia. Bab kesembilan menceritakan pengalamannya memimpin Batavia. Bab kesepuluh lebih banyak menceritakan pengalamannya selama melawat ke Eropa.

\section{Analisis Memoar}

Ketika membaca memoar ini terkesan kuat adanya pergulatan batin dan pemikiran Pangeran Ahmad Djajadiningrat. Dalam babakan kehidupannya sejak kecil hingga dewasa, ada konflik-konflik peran yang dialaminya.

Bagi Djajadiningrat kecil, menjadi anak bupati tidaklah selalu mengenakkan. Santri-santri lain sering memperolok-olok dirinya sebagai anak priyayi. Kondisi tersebut tentu saja kontras dengan kemudahan yang diterima di rumah ayahnya. Hal ini yang membuatnya tertekan. Masyarakat Banten yang relijius membenci segala hal yang berkaitan dengan kolonial Belanda. Mereka menganggap haram menerima gaji dari pemerintah kolonial. Bahkan ada anak wedana yang mengalami perlakuan tidak menyenangkan.

Meski mengalami kejadian yang tidak mengenakkan, banyak pengalaman pelajaran yang diterimanya. Itulah sebabnya saat ia harus meninggalkan pesantren untuk sekolah, ada perasaan yang menghimpit dadanya seperti dituliskannya sebagai berikut: 
"Pada mulanya saya enggan meninggalkan pesantren itu karena hati amat melekat kepada ilmu yang sedang dipelajari. Belum juga sempat duduk di rumah (di Kramat Watu), tiba-tiba ayahku menerima surat dari saudaranya yang sulung, Raden Adipati Soetadiningrat, yang pada masa itu menjadi Bupati di Pandeglang. Ia menulis bahwa masa untuk sekolah bagiku sudah tiba. Oleh sebab itu saya selekas-lekasnya disuruh ke Pandeglang untuk mengunjungi sekolah yang akan dibukanya (Djajadiningrat, 1996: 28)."

"Sesungguhnya amat berat bagiku untuk memutuskan ilmu yang sedang kutuntut, karena besar keinginanku untuk menjadi ulama besar yang terkenal. Tapi apa boleh buat, akhirnya saya tunduk kepada perintah ayah ibu (Djajadiningrat, 1996: 29)."

Tekanan terhadap Achmad selama mengikuti pendidikan tidak lantas berhenti setelah berhenti dari pesantren. Bila dahulu ia sering diperolok teman-teman sebangsanya, selanjutnya ia sering dipandang sebelah mata oleh teman sekelasnya yang berkebangsaan Eropa.

Seketika itu juga sadarlah saya bahwa sikap serasa dan sesama yang dijunjung tinggi di pesantren tidaklah demikian di sekolah yang baru ini, justru sebaliknya. Budi bahasa guru, kesabarannya, dan sikapnya terhadap saudara sepupuku yang anak Bupati sangat jauh berbeda dengan perlakuannya terhadap murid-murid lain (Djajadiningrat, 1996: 31).

Saat bersekolah di Inlandsche Tweede Klasse School dan Europeesche Lagere School, ia merasakan adanya perubahan yang cukup mencolok, terutama dari penampilannya. ....tak lama kemudian saya berganti rupa. Rambutku yang panjang diguntingnya. Saya memakai pakaian bekas anak sulungnya.

.....rupaku sudah bukan lagi seperti anak Banten, tetapi serupa anak Ambon atau anak campuran Belanda (Djajadiningrat, 1996: 80).

Sebagaimana dituliskannya dalam memoar, ia tidak merasa nyaman dengan kondisi demikian. Bahkan untuk menutupi identitasnya, gurunya memberi nama baru, Willem van Bantam "Voortan heet je niet meer Achmad, maar Willem van Bantam" (1996: 83). Tentu saja tujuannya, agar lebih diterima di lingkungan anak-anak Eropa yang rasis.

Komunikasi yang intensif Snouck Hurgronje makin memperluas wawasannya. Di bawah didikan Snouck Hurgronje, Djajadiningrat terus mengasah asa untuk memajukan negerinya. Ia berkeyakinan apa yang diperjuangkan Snouck Hurgroje semata-mata untuk kemajuan kaum pribumi.

Belum lama ia tinggal di negeri ini, namun ia sudah yakin bahwa di tanah Jawa harus dibangun satu generasi yang cukup berilmu dalam semua cabang ilmu pengetahuan. Dengan tidak jemu-jemunya beliau mencari kesempatan bagi para pribumi agar dapat menuntut ilmu dan menerima pendidikan tinggi (Djajadiningrat, 1996: 74).

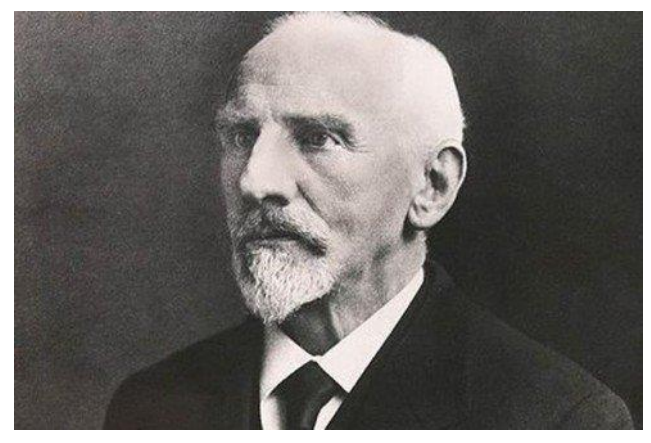

Foto 3. C. Snouck Hurgronje,

Penggagas Politik Asosiasi

Sumber: https://www.islampos.com 
Kebanyakan prasangka, menurut Achmad, yang membuat gagasan Snouck Hurgonje sering disalahpahami kaum pribumi. Prasangka itu muncul tidak saja dari kaum pribumi, tetapi bangsa Eropa yang tidak menginginkan kaum bumiputra mengalami kemajuan.

Di pihak orang Jawa sendiri cita-cita mulia Dr. Snouck Hurgronje tidak mendapat dukungan. Orang tua Jawa pada dewasa itu ragu-ragu memberikan kesempatan karena dipengaruhi oleh situasi dan kedudukan mereka dalam masyarakat, karena pertimbangan keagamaan serta mentalitas orang Eropa terhadap pribumi (Djajadiningrat, 1996: 75).

Di satu sisi, ia amat yakin bahwa upaya luhur Snouck Hurgronje yang dengan sabar membimbingnya mampu membuka hati terhadap pengetahuan, alam pikiran dan kejiwaan orang Belanda. Di sisi lain, ia yakin pendidikan yang diterimanya tidak akan mengasingkannya dari kaum pribumi, tempat dimana ia berpijak (Djajadiningrat, 1996: 83).

Meski ia bersekolah di Batavia, setiap kali pulang ke rumah, ibunya selalu menasihati dengan cerita-cerita dalam tembang Jawa yang berlatar pelajaran/pepeling dari Babad Banten serta Serat al-Anbiya (kisah para nabi). Ia kemudian menulis kembali puisi yang biasa ditembangkan ibunya: "wedi asih ing wong toea, setia toehoe ing Sang Aji, Ratoe ingkang angreh praja, noehoni sakersa neki, soemoedjoed lahir lan batin, ikoe sadjatining elmoe, dadasaring kasatrian (Patuh dan mengasihi orang tua, tetap setia mengabdi pada Yang Mulia, Ratu yang memerintah negeri, tetaplah menghargai semua titahnya lahir dan batin, menghormati mereka, itulah ilmu yang sebenarnya, sebagai dasar dari kepahlawanan (Fadilah, 2007: 4).

Diskriminasi ras oleh bangsa kulit putih bahkan berlanjut hingga ia mulai menanjak dewasa. Cemoohan dan ejekan diterimanya ketika berkenalan dengan seorang pemuda Belanda. Ia juga pernah ditolak pejabat kolonial untuk berbicara dengannya dalam bahasa Belanda ketika pertama kali memasuki karir di birokrasi pemerintahan. Ia juga pernah disebut "kera hitam" (Wat is dat voor een aap?) ketika berada di ruang makan di sebuah hotel. Orang Belanda mengira bahwa Achmad yang mengenakan kain, jas model Jawa, destar dan selop serta makan dengan sendok dan garpu tidak mengerti yang mereka perbincangkan (Watson, 2000: 60).

Agaknya meski zaman telah memasuki abad ke-20, orang-orang kulit putih menganggap aneh pribumi yang makan dengan sendok dan garpu serta minum anggur serta berbicara bahasa Belanda.

Di tengah kuatnya diskriminasi rasial, Achmad meyakini bahwa persamaan bangsa Timur dan Barat lebih banyak dibandingkan perbedaannya. Keduanya memiliki kelebihan dan kekurangannya masing-masing. Hanya saja, orang Barat mampu menanggulangi kekurangannya dan mengembangkan kelebihannya (Labrousse, 1971: 105).

Dalam posisi bupati dan anggota Volksraad, Achmad mendorong pertumbuhan gerakan kebangsaan. Achmad pernah terlibat dalam panitia untuk otonomi Hindia bersama Bupati Bandung dan Jepara. Achmad mendorong perlu adanya kebebasan dan kemerdekaan bagi otonomi Hindia. Namun, karena aktivitasnya itu, ia diminta mengundurkan diri dari pemerintah Hindia Belanda (Kartodirdjo, 1992: 139).

Achmad memiliki perhatian besar untuk memajukan rakyatnya melalui pendidikan. Pada tahun 1924, ia mendirikan himpunan untuk Landbouw Bedrijff School (sekolah pengusahaan pertanian) di Serang. Sayangnya, sebelum sekolah tersebut berjalan, Achmad hijrah ke Batavia dalam kedudukannya sebagai Bupati Batavia (Lubis, 2004: 135). 


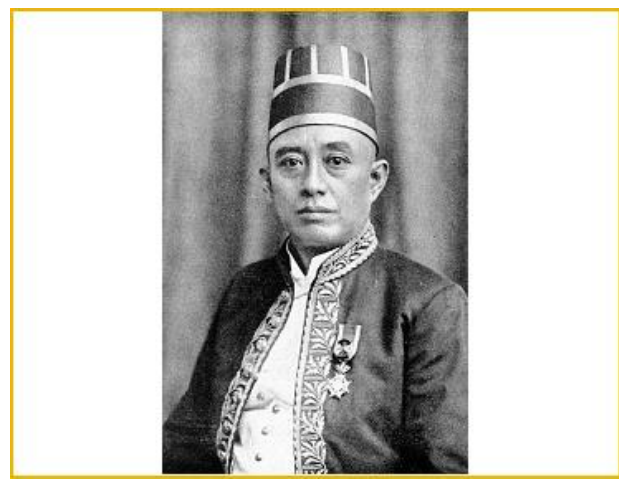

Foto 2. PAA Achmad Djajadiningrat Sumber: http://collectie.tropenmuseum.nl

Pada tahun 1929, Ahmad melawat ke Jenewa sebagai penasihat dari utusan Belanda pada permusyawaratan Volkenbond (Perserikatan Bangsa) dan Internationale Arbeids Conferentie (Konferensi Internasional Perburuhan). Setelah kembali dari Eropa, ia ditunjuk sebagai anggota Raad van Indie.

Achmad berperan penting dalam mendorong perubahan di tanah Banten. Ketika Raden Gunawan datang menghadap kepadanya, dan meminta izin mendirikan SI, tanpa prasyarat Achmad langsung menyetujuinya (Frederick dan Soeri Soeroto, 1991: 149).

Gerakan Sarekat Islam dapat leluasa berkembang di Banten. Sebagai bupati, Achmad memberi dukungan yang kuat, meski tidak terlibat dalam organisasi pergerakan itu. Hal tersebut berbeda dengan penguasa pribumi di daerah lain yang umumnya takut terlibat dengan pergerakan. Sarekat Islam merupakan organisasi pribumi yang berada di bawah pengawasan pemerintah kolonial. Achmad, bahkan, menyarankan agar adiknya, Hasan, menjadi pimpinan SI di Banten (Frederick dan Soeri Soeroto, 1991: 149). Kelak, Hasan Djajadiningrat memainkan peran penting dalam pergerakan SI di Banten. SI Banten terus berkembang sehingga memiliki surat kabar Mimbar dan perserikatan dagang Piroekoen Pribumi.

Kelahiran SI merupakan peristiwa yang menggembirakan, pernyataan dari pemikiran bersama yang dapat berubah menjadi perjuangan yang harus dipertahankan (Djajadiningrat, 1996: 346).

Oleh karena hubungan darahnya dengan Hasan, Bupati Achmad Djajadiningrat sering dituduh menjadikan SI sebagai kendaraan politiknya untuk mengeritik pemerintah. Ia dianggap memberikan pengaruh yang besar pada Hasan (Djajadiningrat, 1996: 350).

Kisah lain tentang dukungan Bupati Achmad Djadjadiningrat terhadap pergerakan diceritakan M. Tabrani. Ia murid OSVIA (Opleiding School Voor Indische Ambtenaren) yang aktif berorganisasi. Karena keaktifannya di cabang Jong Java, ia diancam akan dikeluarkan dari sekolah pendidikan pegawai pribumi tersebut. Berkat campur tangan Bupati Achmad Djajadiningrat, Tabrani dapat melanjutkan bersekolah di OSVIA dan tetap aktif di Jong Java. Syaratnya, rapat-rapat Jong Java tidak keluar dari lingkungan OSVIA (Tabrani, 1996: 446).

Achmad Djajadiningrat menginsyafi selama menjabat dari usia 24 sampai 50 tahun, haluan politik kolonial beralih pada upaya memajukan kesejahteraan dan kecerdasan rakyat Hindia Belanda.

...semua perubahan yang ditujukan untuk memajukan rakyat tidak akan mudah dijalankan bila pihak yang memegang kendali pemerintahan, yaitu orang Barat, tidak dengan terus terang dan tidak dengan komitmen untuk mendorong rakyat maju, terutama bila rakyat itu tidak tahu akan arti hidup sepakat, hidup bersatu, dan hak-hak seorang manusia (Djajadingrat, 1996: 254).

Di zaman yang sedang berubah, ia menakar posisi bupati. Penguasa pribumi tersebut sebenarnya mengetahui apa yang menjadi kesulitan dan kekurangan bagi rakyat pribumi. Namun mereka tidak mempunyai kuasa dan tidak mempunyai jalan untuk menyampaikan gagasan muka 
di hadapan gubernemen maupun forum umum (Djajadiningrat, 1996: 299).

Sebagai perpanjangan tangan dari pemerintah kolonial, posisi bupati terombang-ambing dalam di dua posisi. Oleh karena itu, untuk mengambil putusanputusan penting harus mempertimbangkan banyak hal. Akan tetapi kebanyakan bupati menyadari bahwa gerakan nasionalisme yang semakin hebat dapat membahayakan posisi para ambtenaar.

Ambtenaar harus berhati-hati berlayar di antara karang-karang yang berbahaya, tetapi harus tetap seimbang. Jika kurang bijaksana, niscaya akan ditumbangkan arus (Djajadiningrat, 1996: 329).

Sikap bupati yang serba mendua dan hati-hati tidak jarang menimbulkan sikap antipati kelompok pergerakan. Dalam memoarnya disebutkan, pernah ada seorang pemimpin pergerakan yang mengecamnya. Katanya, jika mereka (pemerintah Hindia Belanda) yang menang, maka Achmad yang akan digantung terlebih dahulu dan jika mereka menang, maka ia yang pertama-tama akan dipancung (Djajadiningrat, 1996: 329)

Tabel 1. Tonggak Sejarah dan Jiwa Zaman

\begin{tabular}{|c|c|c|}
\hline \multicolumn{3}{|c|}{ Jiwa Zaman } \\
\hline FASE & $\begin{array}{c}\text { JIWA } \\
\text { ZAMAN }\end{array}$ & ANTITESIS \\
\hline \multirow{3}{*}{$\begin{array}{l}\text { Pergerakan } \\
\text { Nasional } \\
1900-1942\end{array}$} & $\begin{array}{l}\text { Kolonialisme } \\
\text { Belanda }\end{array}$ & $\begin{array}{l}\text { Munculnya } \\
\text { golongan } \\
\text { inteligensia }\end{array}$ \\
\hline & $\begin{array}{l}\text { Ketidaksamaan } \\
\text { (inequality) }\end{array}$ & $\begin{array}{l}\text { Organisasi } \\
\text { gaya modern }\end{array}$ \\
\hline & Ketidakadilan & Tumbuhnya \\
\hline \multirow[t]{3}{*}{$\begin{array}{l}\text { NASIO- } \\
\text { NALISME }\end{array}$} & $\begin{array}{l}\text { Priveledge- } \\
\text { underpriveledge }\end{array}$ & $\begin{array}{l}\text { sekolah- } \\
\text { sekolah }\end{array}$ \\
\hline & $\begin{array}{l}\text { Kontradiksi- } \\
\text { Konflik }\end{array}$ & $\begin{array}{l}\text { Wawasan } \\
\text { modernisme }\end{array}$ \\
\hline & $\begin{array}{l}\text { Politik etis } \\
\text { bermata ganda }\end{array}$ & $\begin{array}{l}\text { Paham } \\
\text { kebangsaan }\end{array}$ \\
\hline
\end{tabular}

Meski demikian, keberpihakan pada dunia pergerakan diperlihatkannya dengan jelas. Ketika cabang Indische Partij dibentuk di Serang, ia mengikuti gerak organisasi tersebut dengan saksama. Anggota Indische Partij terdiri dari orangorang Indo, pribumi terpelajar, dan orang Cina. Sebagai bupati, Djajadiningrat sering ditarik-tarik untuk masuk dalam organisasi tersebut. Wartawan dan mata-mata pemerintah sering memantau gerak-gerik Bupati Djajadiningrat bila hadir di rapatrapat organisasi (Djajadiningrat,1996: 344).

Agaknya simpati Achmad Djajadiningrat terhadap gerakan kebangsaan tidak dapat disembunyikan. Ia menilai keberadaaan Indische Partij bermanfaat bagi usaha mengurangi perasaan inferior pribumi terhadap orangorang Indo, dan menimbulkan kesadaran orang pribumi mengenai persamaan hak dan keadilan (Djajadiningrat, 1996: 344).

Sesungguhnya politik asosiasi tidak sepenuhnya berhasil. Meski secara lahiriah terjadi perubahan pada diri pangreh praja karena pengaruh Barat, mereka tetap melanjutkan tata kehidupan pribadinya secara tradisional. Meski terkena pengaruh Barat, mereka masih memiliki ikatanikatan keluarga dan ikatan lainnya yang menghubungkan mereka dengan masyarakatnya sendiri, dan masih tetap mempunyai cara-cara berpikir yang dapat dikatakan "tradisional" (Legge, 1993: 27). Perubahan lebih banyak terjadi pada priyayi rendahan yang berusaha keras mencari tempat dalam jenjang pemerintahan (van Niel, 1984: 45-46).

Tabel 2. Bagan peran ganda bupati masa kolonial 


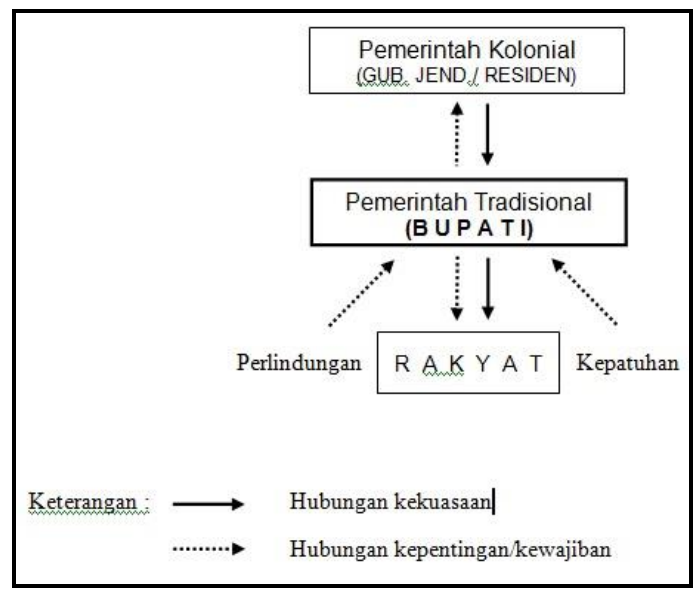

Sumber: Hardjasaputra (2004: 59)

Pemerintah kolonial memperkuat kekuasaan tradisional pangreh praja hasil didikan Barat dengan pemberian simbolsimbol status dan atribut-atribut kebesaran, seperti gelar kepangkatan tradisional, benda-benda untuk upacara kebesaran, tanda-tanda jasa, dan lain-lain. Hal itu menambah legitimasi kepemimpinan tradisional bupati (Hardjasaputra, 2004: 16).

Pemerintah kolonial tetap mempertahankan pangreh praja sebagai penghubung antara pemerintah dengan rakyat. Pemerintah bahkan menempatkan para pangreh praja sebagai unsur sosial yang dipaksa beradaptasi terhadap perubahan politik serta nilai-nilainya. Di sinilah terjadi ambivalensi. Para pangreh praja berdiri di dua kaki. Satu kaki hidup dalam alam tradisional dengan nilai paternalistik dan feodalnya, dan kaki lainnya dalam dunia modern dengan nilainilai baru yang disesuaikan dengan sistem sosial-politik yang sedang berjalan. Pada gilirannya hal tersebut menghambat elit birokrasi pribumi untuk berperan sebagai inovator perubahan sosial (Sudarno, 2006: 9).

Pendidikan kolonial sebagai instrumentasi politik asosiasi pada gilirannya melahirkan kontradiksi yang dipicu oleh adanya diskriminasi dalam sistemnya sendiri. Sebagian besar orangorang Belanda masih menganggap rendah terhadap orang-orang pribumi walaupun berpendidikan tinggi. Sementara, para elit tradisional yang terbaratkan menganggap bahwa dengan memakai simbol-simbol kolonial, mereka lebih dapat diterima dan sejajar dengan bangsa asing. Suatu hasrat yang dalam kenyataannya sering tidak terealisasikan. Bagi Achmad, tantangantantangan semacam itu justru semakin mendorong dirinya untuk belajar dan bekerja lebih keras sebagai pegawai pemerintah dan pelayan masyarakat.

Dalam memoar ini Achmad Djajadiningrat tidak hanya menjadi orang yang terlibat, namun ia juga saksi dari perubahan. Ia mencatat adanya perubahan gaya priyayi-priyayi muda. Dahulu para priyayi lebih sering menanyakan tempat membeli kuda yang bagus. Keahlian menjinakkan juga adalah sebuah prestise tersendiri. Sekarang terjadi perubahan. Mereka bertanya tempat di mana mereka dapat mendapatkan pena yang bagus (Djajadiningrat, 1996: 257).

Pena menjadi penanda yang penting di tanah Hindia pada awal 1900an. Para masa itu, priyayi dinilai berdasarakan kemampuan surat-menyurat, menulis laporan dan membuat rekomendasi kebijakan kepada pemerintah kolonial (Djajadiningrat: 257).

\section{PENUTUP}

Memoar Pangeran Aria Achmad

Djajadiningrat merupakan refleksi otentik pengalaman seorang putra pribumi yang menempuh pendidikan kolonial. Dengan latar adat-istiadat, agama, dan lingkungannya keluarganya ditambah dengan pendidikan Barat telah mengubahnya menjadi manusia modern. Achmad menyadari bahwa di tengah situasi yang berubah, asas keturunan tidak cukup kuat untuk mengemban amanat di kalangan masyarakat pribumi. Hanya dengan pendidikan Barat lah, ia mampu berbuat lebih banyak untuk kemajuan rakyatnya. Ia ingin agar anak pribumi sejajar dengan bangsa kulit putih. 
Tokoh yang memeroleh julukan "macan Banten" ini menyadari bahwa tantangan yang dihadapinya tidaklah mudah. Menjadi bupati di era semakin mengerasnya pergerakan nasional merupakan hal yang tidak menguntungkan. Selain ia sering berlainan pendapat dengan pemerintah kolonial, ia juga berhadapan dengan bangsanya sendiri yang menganggapnya bagian dari kekuasaan kolonial.

Kompetensi Achmad Djajadiningrat sebagai pejabat pemerintahan cukup teruji. Achmad Djajadiningrat termasuk di antara empat bupati yang cakap dalam membaca dan menulis dalam bahasa Belanda. Achmad Djajadiningrat menjadi manusia rasional yang tumbuh dalam sistem pendidikan Barat. Bila merujuk pada tujuan politik asosiasi Snouck Hurgronje, tujuan tersebut tidak sepenuhnya mencapai hasil yang diharapkan. Sebagai bupati yang senantiasa di awasi para pejabat Belanda dalam sistem pemerintahan kolonial, ia memiliki banyak keterbatasan untuk berbuat lebih banyak untuk kaum pergerakan. Achmad ibaratnya tokoh di belakang layar yang berbuat untuk bangsanya dengan caranya sendiri. Pikiran-pikiran Achmad Djajadiningrat yang sarat dengan ide-ide kemajuan dan kemandirian bangsanya cukup mencuat di tengah deru kaum pergerakan. Inilah antitesis dari tujuan politik asosiasi yang tidak mampu sepenuhnya dikontrol oleh politik kolonial.

Achmad masih memiliki keyakinan bahwa dalam sistem kolonial masih ada nilai kebaikan yang dapat membawa bangsa ke arah kemajuan. Bagi Achmad, bangsa Barat dan Timur memiliki banyak kesamaan. Yang menjadi pembedanya adalah bangsa Barat mampu menyempurnakan kualitas hidupnya. Achmad menyadari bahwa kelak suatu saat bangsa Indonesia harus berdiri di atas kakinya sendiri, terlepas dari pemerintahan asing.

Memang bukan merupakan pekerjaan mudah untuk menempatkan posisi seorang tokoh dalam pergerakan kebangsaan hanya dari posisi formalnya. Agaknya persoalan ini lebih pada dominasi arus utama ideologis dan jiwa zamannya. Salah seorang elit pribumi paling menonjol pada awal abad ke-20 ini memilih untuk berjuang di dalam pemerintahan Hindia Belanda untuk memajukan kaum bumiputera. Selain itu, menilai peristiwa yang terjadi di masa lampau dengan cara pandang kekinian sangat mungkin menimbulkan anakronisme sejarah. Penggunaan generalisasi yang cenderung menyesatkan dengan menyatakan seluruh orang pribumi yang bekerja dalam pemerintahan Hindia Belanda sebagai anasionalis, juga bukan pandangan yang bijak. Biarlah generasi sekarang membaca memoar tersebut apa adanya: hitam dan putihnya.

\section{DAFTAR SUMBER}

1. Arsip dan Dokumen Resmi Tercetak

Indonesia. Arsip Nasional. 1976. Memori Serah Jabatan 1921-1930 (Jawa Barat). Jakarta: ANRI.

1980.

Memori Serah Jabatan 1931-1940 (Jawa Barat). Jakarta: ANRI.

Regeerings Almanak vor Nederlandsche-Indie, 1879-1942.

\section{Buku}

Djajadiningrat, Achmad. 1996. Memoar Pangeran Aria Djajadiningrat. Jakarta: Paguyuban Keturunan Pangeran Aria Achmad Djajadiningrat.

Frederick, William H dan Soeroto, Soeri. 1991. Pemahaman Sejarah Indonesia Sebelum dan Sesudah Revolusi. Jakarta: LP3ES.

Habsjah, Atashendartini et al. 2007. Perjalanan Panjang Anak Bumi. Jakarta: Yayasan Obor Indonesia.

Hardjasaputra, A. Sobana. 2004. "Bupati di Priangan; Kedudukan dan Peranannya pada Abad Ke-17- Abad Ke19”. dalam Seri Sundalana 3. Bandung: Pusat Studi Sunda. 
Hisyam, Muhammad dan Ardhana, I Ketut (eds.). 2012.

Indonesia dalam Arus Sejarah: Masa Pergerakan Kebangsaan. Jilid 8. Jakarta: Ichtiar Baru van Hoeve-Kemendikbud.

Kartodirdjo, Sartono. 1984.

Pemberontakan Petani Banten 1888. Jakarta: Pustaka Jaya.

1992.

Pendekatan Ilmu Sosial dalam Metodologi Sejarah. Jakarta: Gramedia. 1992.

Pengantar Sejarah Indonesia Baru: Sejarah Pergerakan Nasional dari Kolonialisme sampai Nasionalisme. Jilid 2. Jakarta: Gramedia.

Klinken, Gerry.2008.

"Aku yang Berjuang": Sebuah Sejarah Penulisan tentang Diri Sendiri pada Masa Orde Baru", dalam Nordholt, Henk Schulte, Bambang Purwanto, dan Ratna Saptari (eds.). Perspektif Baru Penulisan Sejarah Indonesia. Jakarta: Yayasan Obor Indonesia, hlm. 125-154.

Legge, J.D. 1993.

Kaum Intelektual dan Perjuangan Kemerdekaan: Peranan Kelompok Syahrir. Jakarta: Pustaka Utama Grafiti.

Moriyama, Mikihiro. 2005.

Sundanese Print Culture and Modernity in 19th Century West Java. Singapore: Singapore University Press.

Nagazumi, Akira. 1989.

Bangkitnya Nasionalisme Indonesia: Budi Utomo 1908-1918. Jakarta: Pustaka Utama grafiti.

Nasution, S. 2011. Sejarah Pendidikan Indonesia. Jakarta: Bumi Aksara.

van Niel, Robert. 1984.

Munculnya Elit Modern Indonesia. Terjemahan Zahara Deliar Noer. Jakarta: Pustaka Jaya.

Nursam, M. 2002.

Pergumulan Seorang Intelektual: Biografi Soedjatmoko. Jakarta: Gramedia.

Lubis, Nina Herlina. 2004.

Banten dalam Pergumulan Sejarah. Jakarta: LP3ES.
Pranoto, Suhartono W. 2010.

Teori dan Metodologi Sejarah. Yogyakarta: Graha Ilmu.

Supardan, Dadang. 2009.

Pengantar Ilmu Sosial; Sebuah Kajian Pendekatan Struktural. Jakarta: Bumi Aksara.

Sutherland, Heather. 1983.

Terbentuknya sebuah Elit Birokrasi. Jakarta: Sinar Harapan.

Swantoro, P. 2002.

Dari Buku ke Buku; Sambung Menyambung menjadi Satu. Jakarta: KPG.

Tabrani, M. 1996.

"Macan Banten dikurung Belanda di Batavia", dalam Djajadiningrat, Achmad. Memoar Pangeran Aria Djajadiningrat. Jakarta: Paguyuban Keturunan Pangeran Aria Achmad Djajadiningrat, hlm. 445456.

\section{Jurnal dan Majalah}

Daud, Safari. 2013.

"Antara Biografi dan Historiografi; Studi 36 buku biografi di Indonesia", dalam Analisis, Vol. XIII, Nomor 1, Juni 2013, hlm. 243-270.

van Dijk, Kees. 2010.

"The Elitist Premises of Snouck Hurgronje's Association Fantasy", dalam Studia Islamika, Vol. 17, No. 3, 2010, hlm. 407-439.

Ismarini, Ani. 2014.

"Kedudukan Elit Pribumi dalam Pemerintahan di Jawa Barat (19251942)", dalam Patanjala Vol. 6 No. 2, Juni 2014, hlm. 179-192.

Labrousse, Pierre. 1972.

Le Prince A.A. Djajadiningrat à Marseille. Archipel. Volume 3, 1972. pp. 102-105.

Zed, Mestika. 2012.

"Engku Mohammad Sjafe'i dan INS Kayutanam: Jejak Pemikiran Pendidikannya", dalam TINGKAP Vol. VIII No. 2 Th. 2012, hlm. 173-188. 


\section{Skripsi dan Makalah}

Fadilah, Moh. Ali. 2007.

Posisi Perempuan dalam Historiografi Tradisional Banten. Makalah dalam Temu Tokoh "Merefleksikan Perjuangan Perempuan Banten sebagai Upaya Mempertautkan Ingatan Kolektif. Serang, 24 April 2007.

Sudarno. 2006.

Kerja Magang: Dari Juru tulis Sampai Bupati di Hindia Belanda Menjelang Abad XX. Makalah dalam Konferensi Nasional Sejarah, Jakarta 13-16 November 2006.

Tirta, Tyson. 2012.

Meneliti Tingkat Kesejahteraan Masyarakat Jawa; Mindere Welvaart Commissie, 1902-1914. Skripsi. Depok:

Fakultas Ilmu Pengetahuan Budaya

Program Studi Ilmu Sejarah 